\title{
Hydro-Morphometric Modeling for Flood Hazard Vulnerability Assessment of Old Brahmaputra River Basin in Bangladesh
}

\author{
Rathindra Nath Biswas ${ }^{1 *}$, Md. Juel Mia², M. Nazrul Islam ${ }^{1}$ \\ ${ }^{1}$ Department of Geography and Environment, Jahangirnagar University, Bangladesh \\ ${ }^{2}$ Institute of Disaster Management and Vulnerability Studies, University of Dhaka, Bangladesh
}

Submission: February 16, 2018; Published: April 18, 2018

*Corresponding author: Rathindra Nath Biswas, Department of Geography and Environment, Jahangirnagar University, Savar, Dhaka-1342, Bangladesh, Email: rathingeoju39@gmail.com

\begin{abstract}
The present research introduces hydro-morphometric modeling to assess flood hazard vulnerability in old Brahmaputra River Basin in Bangladesh. Hydro-morphometric modeling is a spatial analysis in a GIS environment that has been applied for the estimation of flood hazard vulnerability. In this study the developed methodology processes information of seven parameters namely basin, flow accumulation, flow direction, stream order, stream length, stream density and drainage density. By applying Horton's and Strahler's formula of stream order, stream density and drainage density of old Brahmaputra River Basin are calculated. According to Horton's stream density and drainage density reflects the runoff and discharge status of a basin which also revealed that basin having high stream density and drainage density is most vulnerable to flooding. The old Brahmaputra River Basin subdivided into five sub-Basin named as sub-basin A, B, C, D and E and their stream density are $1.318 \mathrm{~km}^{-2}, 1.113 \mathrm{~km}^{-2}, 1.2009 \mathrm{~km}^{-2}, 1.028 \mathrm{~km}^{-2}, 0.998 \mathrm{~km}^{-2}$ and their drainage density are $0.713 \mathrm{~km}^{-1}, 0.690 \mathrm{~km}^{-1}, 0.689 \mathrm{~km}^{-1}, 0.703 \mathrm{~km}^{-1} \mathrm{and}_{0.703 \mathrm{~km}^{-}}$ ${ }^{1}$, respectively. Among the five sub-basins of this river basin, sub-basin A contains high stream and drainage density, which means this basin is most vulnerable to flooding, whereas basin $\mathrm{C}$ and $\mathrm{D}$ are least vulnerable because of its low stream and drainage density. Among the different floods, severe river flooding affects the area of 33.66 hectors agriculture land, 855.27 hectors fallow land, and 548.55 hectors vegetation cover, 275.22 hectors settlements and 177.3 hectors water bodies in this river basin. This study also revealed that agriculture land and resources, and life defence of marginal community of the Old Brahmaputra river basin are vulnerable to flood hazard.
\end{abstract}

Keywords: Hydro-morphometric modeling; Flood hazard vulnerability assessment; Old brahmaputra river basin; High level of poverty; Neighbourhood; Flooding; Destructive floods; Crop production; Livelihoods; Monsoon; Stream density; Stream order

Abbreviations: LFF: Low Flash Flooding; SFF: Severe Flash Flooding; LRF: Low River Flooding; MRF: Moderate River Flooding; SRF: Severe River Flooding; USGS: United States Geological Survey

\section{Introduction}

Bangladesh is one of the most vulnerable countries to the impacts of flood hazard in south Asia. This country is extremely vulnerable to flood because of its geographical location, high population density, high level of poverty, and the reliance of many livelihoods on flood hazard sensitive sectors [1]. Moreover, the climate of the country is strongly influenced by monsoon rainfall which creates flood in three major river basin named as GangesPadma, Brahmaputra-Jamuna, and Meghna River Basin. Though Bangladesh occupies only $7 \%$ of the combined catchment area of the Ganges-Padma, Brahmaputra-Jamuna and Meghana river basin, the country has to drain out $92 \%$ of the flow into the Bay of Bengal [2]. Too much water in the monsoon period affects different sectors along with livelihoods and food security. There is six major destructive floods occurred in 1984, 1987, 1988, 2004 and 2007 since after liberation war of Bangladesh [3]. In 1984 flood about 50,000sq.km area of land was flooding. In 1987 flood about 2,055 people died, flood affected area was 50,000sq.km and losses 1 billon US \$. Among the six floods, more destructive flood was 1988. In the historical memory of Bangladesh most destructive flood was occurred in 1988 and where 61 percent of the country was inundated, 2,000-6,500 people died, about 45 million people become homeless and caused 1.2 million US $\$$. In 1998, flood inundates nearly 100,000 sq. km, damages 500,000 homes and rendered 30 million people homeless, death counted 1,100 people and estimated loss was 2.8 million US \$. In last 2007 flood about 32, 000sq.km area was flooding and 649 people losses their lives and property losses is about 1 billion 
US \$ [4]. Flood visits every year. In 2017, flood visits Bangladesh for two times. Early Flash flood at the Haor region of Bangladesh caused heavy loss of crop production and other life defence. Second flood of 2017 visits northern, north-west and north-east parts of Bangladesh at the time of monsoon season; damaged agricultural production and created human sufferings.

Moreover, the inhabitants of Old Brahmaputra river basin are exposed to flood risk mainly due to geographic location, geological and geomorphological formation, and heavy rainfall during the monsoon and river siltation. In this basin, people understand the risks and still living in the neighbourhood for decades. People of the basin developed some indigenous approaches of their own to adapt against the hazards. Government and non-government organization are also working for the welfare of flood area people.

Therefore, flood risk management needs to overcome national borders, geographic location and socio-economic limitations [5]. Flood risk management usually includes flood risk assessment and flood risk mitigation [6]. This distinction takes into account apart from the hazard also its impact, since the total elimination of risk is neither possible nor efficient. Indisputably, strategies against floods' impact at a region scale require the identification of prone areas [7]. To provide early warning, facilitate quick response and decrease the impact of possible flood events [8] hydro-morphometric modeling, flood hazard zoning and risk for people's resource are better option in flood hazard risk flood Risk management in old Brahmaputra River Basin.

\section{Study Area}

The studied Old Brahmaputra River Basin comprised of nine districts of Bangladesh, namely Sherpur, Jamalpur, Mymensingh, Tangail, Netrokona, Kishoreganj, Brahmanbaria, Narsingdi and Gazipur. Total area of the studied river basin is $6851.58 \mathrm{~km} 2$. The topographic elevation of this river basin extract from DAM satellite image which range $-25 \mathrm{~m}$ to $53 \mathrm{~m}$.

The main river of this Basin is Old Brahmaputra which is one of the main distributaries of the Jamuna (Brahmaputra) that distributes part of Jamuna discharge over a large area of north central region of Bangladesh. The earliest study of the Brahmaputra was made by Rennell who mapped the Brahmaputra as a braided river flowing into the Meghna River and following a course now occupied by a much smaller river known as the Old Brahmaputra. Since then the river has changed course and avulsed into its present course known as the Jamuna River. Gradual tilting caused the Old Brahmaputra River to become antecedent in places, necessitating river scour into slowly or periodically rising, comparatively resistant Pleistocene sediments [9]. Faulting was probably the major cause of the recent shift of the Brahmaputra River from its course east of the Madhupur tract to its present position [10]. The Old Brahmaputra River is at present reduced to a left bank spill channel of the
Brahmaputra River and only active during the high stage of the Brahmaputra River. The discharge and sediment transport through the river is dependent on opening of the off take with the Brahmaputra River [11]. During the recent years, the river basin is more vulnerable to flood due to lower elevation, river siltation and monsoon rainfall. Moreover, Monsoon rainfall overtop the banks of this river causes serious destruction of the inhabitants settlement, Agricultural crops and domestics animals (Figure 1 \& 2).

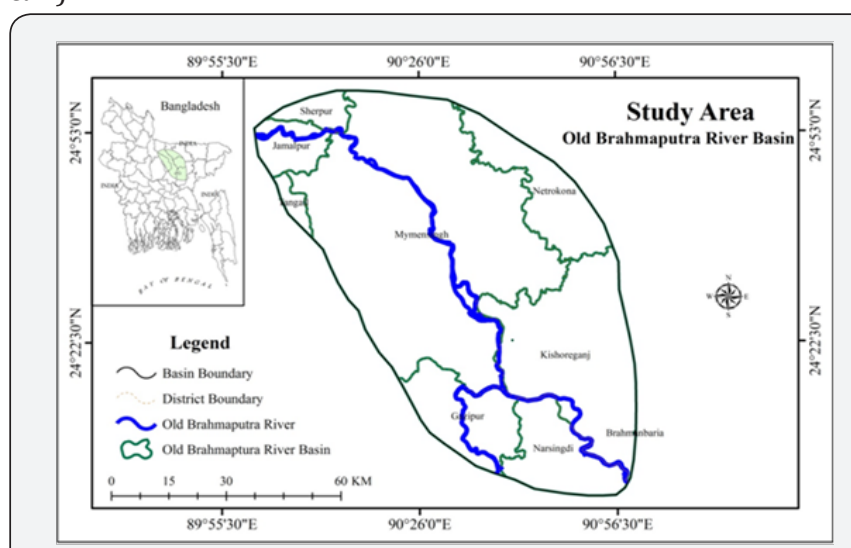

Figure 1: Location of the study area.

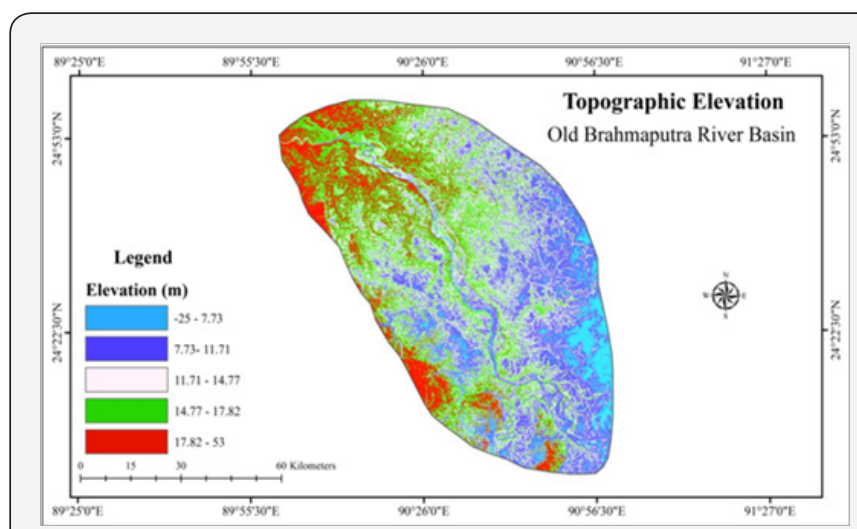

Figure 2: Topographic elevation of Old Brahmaputra River Basin.

Methods and Materials

In this research for identification of stream channels to delineate the extent of regular inundation in Old Brahmaputra River basin satellite Image (DEM) is collected from United States Geological Survey (USGS). By applying Strahler [12], stream ordering method in GIS environment Old Brahmaputra River Basin stream are ordered. For exploration of flood depth grids using spatial analyst tools (hydrological model) and prepare a comprehensive flood zone map which is integrated with flood zoning data of Bangladesh Water Development Board. Predict and determine the potential flood vulnerability and list of vulnerable sectors, elements and resources for the community of old Brahmaputra River Basin Satellite Image (Landsat TM) is also collected from United States Geological Survey (USGS) for Land Use and Land Cover classification using supervised classification of RS tools and techniques for mapping potential flood risk for the community. 


\section{Stream Channel Extraction}

The stream network of the study area is extracted from a series of geo processing tools. According to Strahler [12], the output of this technique creates a stream network grid with stream classification. Strahler's system of classification designates a segment with no tributaries as a first-order stream. Where two first-order stream segments join, they form a secondorder stream segment and so on. The highest stream order in the study area was computed as third. Manual corrections are made by merging the streams of same order with separated nodes.

\section{Stream Order}

To analyze drainage basin, it is needed to determine stream orders. In this study, the channel segment of the drainage basin has been ranked with the lens of Strahler's stream ordering system. According to Strahler [12], the smallest fingertip tributaries are designated as order 1 . Where two first order channels join, a channel segment of order 2 is formed; Where two of order 2 joins, a segment of order 3 is formed.

\section{Stream Length}

In this study, Horton law has been applied to measure stream length (Lu) of Old Brahmaputra River basin. Stream Length reflects surface runoff of a river basin which is one of the essential hydro-morphometric features for assessing flood Results and Discussion hazard vulnerability. According to Horton [13], Stream length of a river basin is higher in first order and gradually decreases in next orders. GIS spatial analysis in hydrological environment is used to compute number of stream in a stream order and their stream length.

\section{Drainage and Stream Density}

Drainage and Stream density are important morphometric parameters to analyze flood risk. The concept of drainage and stream density model developed by Horton [14] has been used in this study to analyze spatial vulnerability of flood in Old Bramhaputra River basin. The core ideas of these models are that a basin having high stream and drainage density is most vulnerable to flooding [13]. With the use of GIS tools and techniques firstly measured stream length and then divided it by total area of the basin to calculate drainage density. Furthermore, stream density computed by counting number of stream and then divided it by area of basin.

$$
\begin{aligned}
& \text { Drainage Density }(D d)=L u / A \\
& \text { Stream Density }(S d)=N s / A
\end{aligned}
$$

Where, Dd is drainage density, Lu is the total stream length of all orders, Sd is stream density, Ns is the total stream of all orders and $A$ is the Basin area $\left(\mathrm{km}^{2}\right)$.

\section{Flood vulnerability of old brahmaputra river basin from hydro-morphometric modeling}

\begin{tabular}{|c|c|c|c|c|c|c|}
\hline \multirow{2}{*}{\multicolumn{2}{|c|}{ Hydro-morphometric Parameter }} & \multicolumn{5}{|c|}{ Sub-Basin } \\
\hline & & \multirow{2}{*}{$\begin{array}{c}\text { A } \\
744\end{array}$} & \multirow{2}{*}{$\begin{array}{c}\text { B } \\
1179\end{array}$} & \multirow{2}{*}{$\begin{array}{c}\text { C } \\
1022\end{array}$} & \multirow{2}{*}{$\begin{array}{c}\text { D } \\
696\end{array}$} & \multirow{2}{*}{$\begin{array}{c}\mathbf{E} \\
489\end{array}$} \\
\hline \multirow{5}{*}{ Stream Order (Horton's Law) } & $1^{\text {st }}$ & & & & & \\
\hline & $2^{\text {nd }}$ & 522 & 452 & 403 & 325 & 333 \\
\hline & $3^{\text {rd }}$ & 151 & 190 & 210 & 191 & 82 \\
\hline & $4^{\text {th }}$ & 64 & 343 & 43 & 20 & 58 \\
\hline & $5^{\text {th }}$ & 89 & 100 & 0 & 42 & 27 \\
\hline Total Streams & & 1570 & 2264 & 1678 & 1274 & 989 \\
\hline Basin Area (sq. km) & & 1190.75 & 2033.49 & 1397.32 & 1239.34 & 990.687 \\
\hline Stream Length (km) & & 847.546 & 1403.246 & 962.8367 & 871.4639 & 679.53 \\
\hline Streams Density $\left(\mathrm{km}^{-2}\right)$ & & 1.318 & 1.113 & 1.2009 & 1.028 & 0.998 \\
\hline Drainage Density $\left(\mathrm{km}^{-1}\right)$ & & 0.713 & 0.69 & 0.689 & 0.703 & 0.686 \\
\hline
\end{tabular}

Table 1: Hydro-morphometric Information of Old Brahmaputra River Basin.

According to Horton's stream density and drainage density reflects the runoff and discharge status of a basin which also revealed that basin having high stream density and drainage density is most vulnerable to flooding. The old Brahmaputra River Basin subdivided into five sub-Basin named as sub-basin A, B, C, D and E and their stream density are $1.318 \mathrm{~km}^{-2}, 1.113 \mathrm{~km}^{-}$ $2,1.2009 \mathrm{~km}^{-2}, 1.028 \mathrm{~km}^{-2}, 0.998 \mathrm{~km}^{-2}$ and their drainage density are $0.713 \mathrm{~km}^{-1}, 0.690 \mathrm{~km}^{-1}, 0.689 \mathrm{~km}^{-1}, 0.703 \mathrm{~km}^{-1}$ and $0.703 \mathrm{~km}^{-1}$, respectively (Figure 3 ) and (Table 1 ). Among the five sub-basins of this river basin, sub-basin A contains high stream and drainage density, which means this basin is most vulnerable to flooding, whereas basin $\mathrm{C}$ is least vulnerable because of its low stream and drainage density.

\section{Community flood vulnerability of brahmaputra river basin}

The flooding area of this river basin is $2956.43 \mathrm{~km}^{2}$, including $0.056139 \mathrm{~km}^{2}$ in Brahmanbaria, $12.527 \mathrm{~km}^{2}$ in Gazipur, $46.0295 \mathrm{~km}^{2}$ in Jamalpur, $114.664 \mathrm{~km}^{2}$ in Kishoreganj, $1926.51 \mathrm{~km}^{2}$ in Mymensingh, $267.303 \mathrm{~km}^{2}$ in Narsingdi district, $533.258 \mathrm{~km}^{2}$ 
in Netrokona, $55.4984 \mathrm{~km}^{2}$ Sherpur and $0.583869 \mathrm{~km}^{2}$ in Tangail district (Figure 4) and (Table 2). Among the studied districts of this river basin, $65 \%$ of area of Mymensingh is vulnerable to flood hazard.

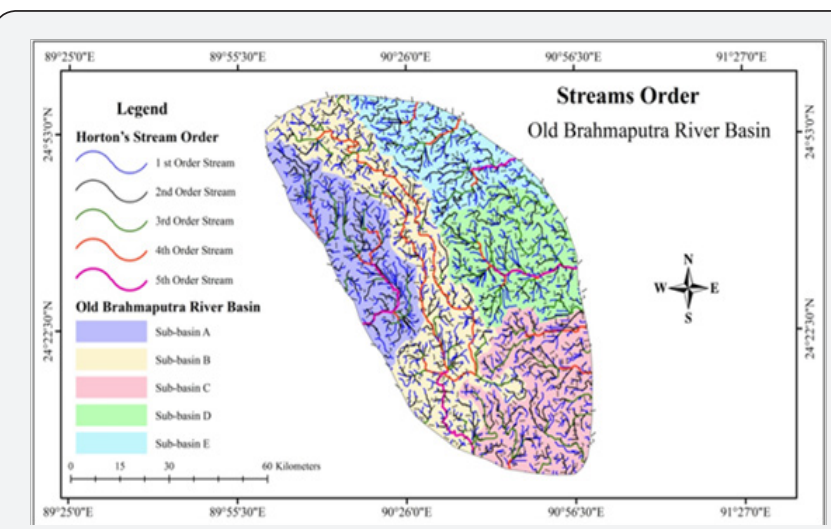

Figure 3: Stream order, and Basin and Sub-basin of Old Brahmaputra River

Table 2: Community Flood Risk of Old Brahmaptura River Basin.

\begin{tabular}{|c|c|c|}
\hline District Name & Flooding Area $\mathbf{( k m}^{\mathbf{}} \mathbf{)}$ & Percentage (\%) \\
\hline Brahmanbaria & 0.05614 & 0.002 \\
\hline Gazipur & 12.527 & 0.424 \\
\hline Jamalpur & 46.0295 & 1.557 \\
\hline Kishoreganj & 114.664 & 3.878 \\
\hline Mymensingh & 1926.51 & 65.163 \\
\hline Narsingdi & 267.303 & 9.041 \\
\hline Netrokona & 533.258 & 18.037 \\
\hline Sherpur & 55.4984 & 1.877 \\
\hline Tangail & 0.58387 & 0.02 \\
\hline Total & 2956.43 & 100 \\
\hline
\end{tabular}

Flood risk for resources of old brahmaputra river basin

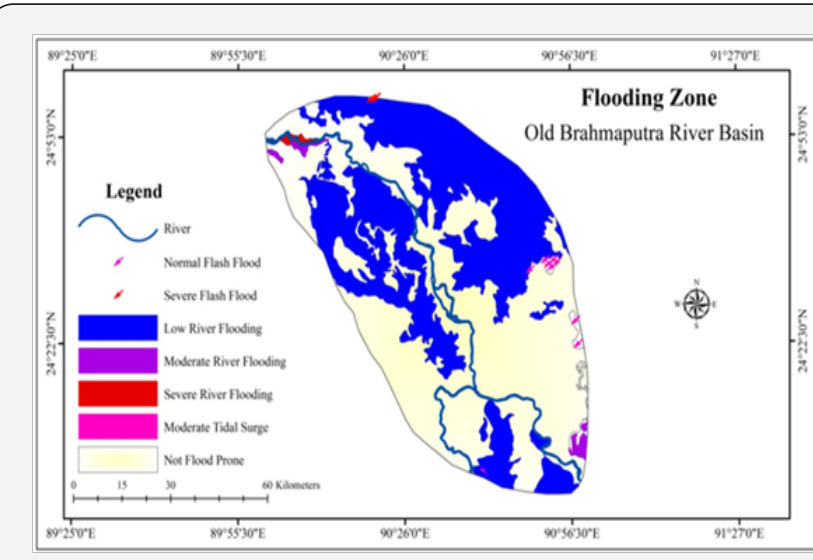

Figure 4: Flooding Zone of Old Brahmaptura River Basin.

In Brahmaputra River Basin land use and land cover classification (Figure 5) revealed that Agricultural Land covers the maximum area of 397444 hectors which is $37 \%$ of total land; fallow land covers the area of 250696 hectors which consists of $24 \%$ of total land; Vegetation covers the area of 153752 hectors which is the $14 \%$ of total land; water bodies covers the area of 147410 hectors which is the $14 \%$ of total land and settlement covers area of 119729 hectors which is $11 \%$ hectors of the research area (Table 3). On the basis of severity flood in Brahmaputra River Basin are classified into 6 such as low flash flood, severe flash flood, low river flood, moderate river flood and severe river flood and storm tidal surge (Figure 4). Low flash flooding affects area of 2719.62 hectors agriculture land, 200.07 hectors fallow land, 336.96 hectors vegetation cover, 396.27 hectors settlements and 84.33 hectors water bodies in this river basin. Severe flash flooding affects area of 157.86 hectors agriculture land, 4.95 hectors fallow land, and 2.7 hectors vegetation cover, 18.54 hectors settlements and 0.63 hectors water bodies in this river basin. Low River Flooding affects area of 128218 hectors agriculture land, 57509.2 hectors fallow land, and 39237.9 hectors vegetation cover, 55319.6 hectors settlements and 5666.4 hectors water bodies in this river basin.

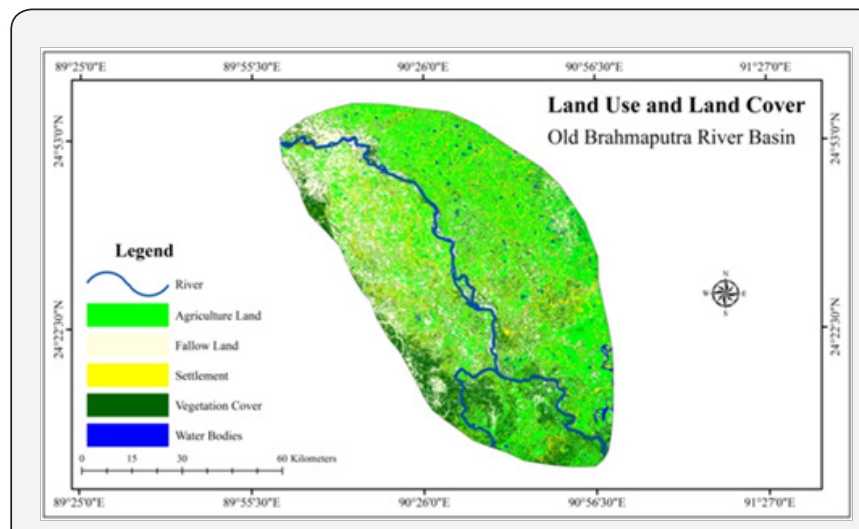

Figure 5: Land Use and Land Cover of Old Brahmaputra River Basin.

Table 3: Land Use and Land Cover of Old Brahmaputra River Basin.

\begin{tabular}{|c|c|c|}
\hline Class & Area (Hectors) & Percentage \\
\hline Agriculture Land & 397444 & 37.178 \\
\hline Fallow Land & 250696 & 23.451 \\
\hline Vegetation Cover & 153752 & 14.382 \\
\hline Water bodies & 147410 & 13.789 \\
\hline Settlement & 119729 & 11.2 \\
\hline
\end{tabular}

Moderate river flooding affects area of 1910.52 hectors agriculture land, 1704.42 hectors fallow land, and 1333.26 hectors vegetation cover, 527.58 hectors settlements and 154.62 hectors water bodies in this river basin. Severe river flooding affects area of 33.66 hectors agriculture land, 855.27 hectors fallow land, and 548.55hectors vegetation cover, 275.22hectors settlements and 177.3 hectors water bodies in this river basin (Table 4) and (Figure 6).

(Note: LFF=Low Flash Flooding, SFF= Severe Flash Flooding, LRF: Low River Flooding, MRF= Moderate River Flooding and SRF: Severe River Flooding) 
Table 4: Flood Risk for Resource of Old Brahmaputra River Basin.

\begin{tabular}{|c|c|c|c|c|c|}
$\begin{array}{c}\text { Flood } \\
\text { Hazard } \\
\text { Class }\end{array}$ & \multicolumn{5}{|c|}{ Flood Risk for Resource (ha) } \\
\hline & $\begin{array}{c}\text { Agriculture } \\
\text { Land (ha) }\end{array}$ & $\begin{array}{c}\text { Fallow } \\
\text { Land }\end{array}$ & $\begin{array}{c}\text { Vegetation } \\
\text { Cover }\end{array}$ & $\begin{array}{c}\text { Settle- } \\
\text { ment }\end{array}$ & $\begin{array}{c}\text { Water } \\
\text { bodies }\end{array}$ \\
\hline LFF & 2719.62 & 200.07 & 336.96 & 396.27 & 84.33 \\
\hline SFF & 157.86 & 4.95 & 2.7 & 18.54 & 0.63 \\
\hline LRF & 128218 & 57509.2 & 39237.9 & 55319.6 & 5666.4 \\
\hline MRF & 1910.52 & 1704.42 & 1333.26 & 527.58 & 154.62 \\
\hline SRF & 33.66 & 855.27 & 548.55 & 275.22 & 177.3 \\
\hline
\end{tabular}

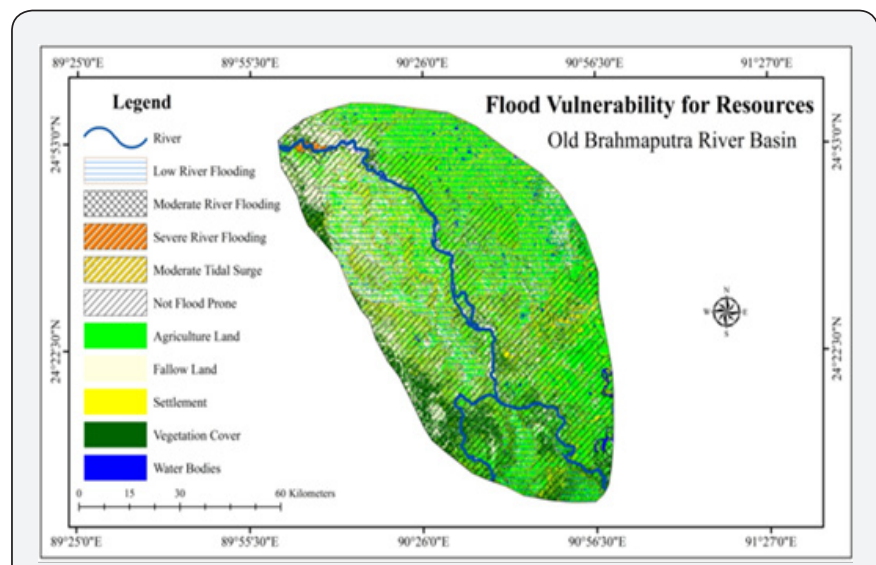

Figure 6: Impacts of Flood on Resources.

From this analysis it can be said that agriculture land and resource of this river basin are more vulnerable and which is life defence of the community of Brahmaputra River basin.

\section{Conclusion}

The drainage network of Old Brahmaputra River Basin reveals that the basin is vulnerable to flooding due to its geotectonic formation and low elevation where over rain often causes flash flood and seasonal flood visit every single year. The flood zoning showed in the study that comparatively north eastern part of the basin area is at more risk that southern part due to elevation and number of streams of high order that carries huge volume of water. Community people of Old Brahmaputra River Basin are more at risk than the actual figures show in the research. As land use classes for assessing resources vulnerability reflect that vegetation and agriculture are proportionally much higher in account of area than settlements that do not mean people are safer, people living in the vicinity live densely due to lack of higher grounds that stays above water. Though people know that they are vulnerable and exposed to disasters the sense of love for the place and locality makes them stay and a few don't even have the ability to move somewhere to settle. Keeping all the risks aside they developed some indigenous knowledge by living there for years where they anticipate hazards and tries to protect and mitigate in their own local capabilities.

\section{References}

1. Agrawala S, Ota T, Ahmed AU, Smith J, Van Aalst M (2003) Development and climate change in Bangladesh: focus on coastal flooding and the Sundarbans. Paris: OECD p. 1-49.

2. Chowdhury MM (2012) A Comprative Study of Disasters Risk Reduction and Livelihood Recovary Program in Japan and Bangladesh.

3. Mo FDM, (2010) National Plan for Disaster Management 2010-2015. Ministry of Food and Disaster Management.

4. Mo EF (2009) Bangladesh Climate Change Strategy and Action Plan. Ministry of Environment and Forests: Governments of the People's Republic of Bangladesh.

5. Schanze J (2006) Flood risk management-a basic framework. In Flood risk management: hazards, vulnerability and mitigation measures 67: $1-20$.

6. Degiorgis M, Gnecco G, Gorni S, Roth G, Sanguineti M, et al. (2012) Classifiers for the detection of flood-prone areas using remote sensed elevation data. Journal of hydrology 470-471: 302-315.

7. Schanze J (2006) Flood risk management-a basic framework. In: Flood risk management: hazards, vulnerability and mitigation measures 67: $1-20$.

8. Tehrany MS, Pradhan B, Jebur MN (2013) Spatial prediction of flood susceptible areas using rule based decision tree (DT) and a novel ensemble bivariate and multivariate statistical models in GIS. Journal of Hydrology 504: 69-79.

9. Kia MB, Pirasteh S, Pradhan B, Mahmud AR, Sulaiman WNA, et al. (2012) An artificial neural network model for flood simulation using GIS: Johor River Basin, Malaysia. Environmental Earth Sciences, 67(1): 251-264.

10. Morgan JP, McIntire WG (1959) Quaternary geology of the Bengal basin, East Pakistan and India. Geological Society of America Bulletin 70(3): 319-342.

11. Coleman JM (1969) Brahmaputra River: channel processes and sedimentation. Sedimentary Geology 3(2-3): 129-239.

12. Noor F (2013) Morphological study of Old Brahmaputra offtake using two-dimensional mathematical model.

13. Strahler AN (1964) Quantitative geomorphology of drainage basin and channel networks. Handbook of applied hydrology.

14. Horton RE (1945) Erosional development of streams and their drainage basins; hydrophysical approach to quantitative morphology. Geological society of America bulletin 56(3): 275-370. 


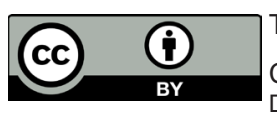

This work is licensed under Creative Commons Attribution 4.0 License DOI: 10.19080/ETOAJ.2018.01.555567

\section{Your next submission with Juniper Publishers will reach you the below assets}

- Quality Editorial service

- Swift Peer Review

- Reprints availability

- E-prints Service

- Manuscript Podcast for convenient understanding

- Global attainment for your research

- Manuscript accessibility in different formats

( Pdf, E-pub, Full Text, Audio)

- Unceasing customer service

Track the below URL for one-step submission https://juniperpublishers.com/online-submission.php 